\title{
Resource Use Efficiency of Yam Production among Smallholder Farmers and Effect to the Environment in the Tropics
}

\author{
Ume S.I. ${ }^{*}$, Kaine A.I.N. ${ }^{2}$ and Ochiaka C.D. ${ }^{3}$ \\ ${ }^{1}$ Department of Agricultural Extension and Management. Federal College of Agriculture Ishiagu, \\ Ivo Local Government Area of Ebonyi State, Nigeria. \\ ${ }^{2}$ Department of Agricultural Economics and Extension, National Open University of Nigeria \\ Km4 Kaduna - Zaria RD, Kaduna, Kaduna State, Nigeria \\ ${ }^{3}$ Department of Agricultural Economics and Extension Enugu State University of Science and \\ Technology Enugu State, Nigeria \\ *umesmilesi@gmail.com
}

Keywords: Resource use, Efficiency, Yam Production, Smallholder, Farmers

\begin{abstract}
Resource use efficiency of yam production among smallholder farmers in Southeast, Nigeria was studied. The specific objectives of the study are to estimate the costs and returns in yam production, determine the allocative efficiency of yam production among small holder farmers, determine the different effects of yam cropping activities to the environment and identify and describe the limiting factor to yam production in the study area. A multi-stage random sampling technique was used to select 240 farmers and from which information needed for the study were elicited using a structure questionnaire. Cost and returns analysis, allocative efficiency model and distributive statistics such as percentage response and frequency distribution table were used to capture the objectives of the study. The result shows that yam production was profitable in the study area. Also, result of the allocative efficiency of the inputs shows that the farmers did not attain optimal allocative efficiency, since they either under - utilized or over utilized their resources. Yam production activities in form of clearing, burning, pesticides use, fertilizer use and tillage could result in among others wild Life habitation, oxygen - carbon dioxide balance, erosion, effect aesthetic, increases soil temperature, reduction of soil nutrient, human health and welfare and conversion of organic nitrogen into mobile nitrates. The constraints to yam production were high cost of labour, poor access to credit, poor access to extension services and high cost of labour. Improving farmers' access to credit, fertilizer and extension contact were recommended.
\end{abstract}

\section{Introduction}

Yams (Dioscorea species) are annual root tuber bearing plants with more than 600 species out of which six are socially and economically important in terms of food, cash and medicine [1]. Some of the yam species are water yam (Dioscorea alata), white yam (Dioscorea rotundata), yellow yam (Dioscorea cayanensis), Chinese yam (Dioscorea esculant) and three-leaf yams [3]. National Root Crop Research Institute (NRCRI) classified yam into wareyam( $>11$ grams), seed yam (259grams $-1 \mathrm{~kg}$ ) and miniset $<50$ grams) [2].

Yam is an important carbohydrate in the diet of many people in tropics and sub-tropics where it is grown as staple [4]. It can be cooked, fried, roasted and processed into pounded yam [5]. The average yam consumption per capita per day in Nigeria was 258 calories [4]. It is a source of income as it provides employment to many rural dwellers either as a producer, marketer or labourer [1]. The yam peels can be use as livestock feeds. Yam in processed form such as yam flour could serve as the country's foreign exchange earnings [4].

Worldwide yam production in 2007 amounted to 52 million tons, of which Africa produced 96\%. Most of the world's production comes from West Africa representing 94\%, with Nigeria alone producing $71 \%$, equalling more than 37 million tons $[1,2,10]$ Studies $[8,9 ; 10]$ show that feat peformed by Nigeria could be substantially be associated to more to increase on the areas of land planted than increases in productivity [1]. Although, there were increases in the cultivated areas, but 
the growth rate decreased from average of $27.5 \%$ between 1986 and 1990 to $3.5 \%$ in 1996 to 2012 [5].

Nevertheless, because of dramatic changes in the country inform of political, economic, social and other production constraints variables, including unavailability of improved varieties, low research zeal due to poor research funding, lax extension commitment to their duties, high levels of post-harvest losses, high production costs, low and declining soil fertility, moisture stress as well as pests and diseases problems, have resulted to low farm production and productivity [5; $11]$.

Indeed, there is no doubt to infer that lots of environmental factors restrict the production of agricultural crops, yam inclusive in most developing countries of Africa, South east Asia, south America and Caribbean. As well these food production systems themselves have lots of negative correlation to the environment especially during pre- production, production and postproduction [9]. Pre-production environmental interactions as relate to agricultural growth, included soil degradation and erosion, the loss of wild biodiversity, loss of food crop genetic diversity and climate change [7]. Those environmental problems as result of crop production, included soil nutrient depletion, water depletion, soil and water contamination with pesticides and fertilizer (organic and inorganic), pest resistance/outbreaks and the emergence of new pests and diseases. While, post-harvest environmental interactions relate to the effects of crop residue disposal, as well as crop storage and processing [6]. However, the low productivity in yam production could be partly be improved through efficiency in the use of productive resources of land, labour and capital $[14 ; 15]$.

Efficiency is generally associated with the possibility of attainment in optimal level of output from a given bundle of input at least cost [16, 17]. Efficiency is distinguished into three types of efficiency, technical, allocation and economic efficiencies. Technical efficiency is the capability of firms to utilize the best practice or technology in the production process so that the minimum possible resources are used to achieve the best or optimum output level [18]. Allocative efficiency or pricing efficiency as asserted by [19] is capable of equating the marginal value product (MVP) of the input of its unit price. Furthermore, allocative efficiency could portray the tangency of price line and isoquant [20]. The combination of technical and pricing efficiency is known as economic efficiency. The need to embark on this research is basically on the fact that efficiency measures is a very important factor of productivity growth especially in our developing agriculture where resources are meagre and opportunities for developing and adopting better technologies have lately started dwindling [21].

In many developing countries including Nigeria, lots of in depth publications on the effects of most staple crops such as rice and maize productions to the environmental [20] but very meager in yam production. In addition, it is not unexpected that considerable research efforts have been centered on the analysis of efficiency at farm level in most sub Saharan Africa, as farmers are not making efficient use of existing input resources [13]. Therefore, there are solemn efforts designed to improve their efficiency and, also to access the effect of the crop production to the environment. It is on these premises that this study anchored upon. Specifically, the objectives of the study are to; (i) estimate the costs and return in yam production, (ii) determine the allocative efficiency of yam production among small holder farmers and (iii) determine the different effects of yam cropping activities to the environment. (iv) identify and describe the limiting factor to yam production in the study area.

\section{Theoretical Framework}

\section{Production Functions}

As reported by [22] production function shows how and to what extent output changes with variation in inputs during a specified period of time. The two concepts of production function are technical efficiency and allocative efficiency. Technical efficiency refers to the ability of producers to obtain a certain level of outputs, while allocative efficiency is the ability to choose the level of inputs that maximizes profit, given factor cost (Olayide et al, 1982). According to [24], productivity is generally measured in terms of the efficiency with which farm resources are converted to output 
within the production process. two measures of productivity namely, partial productivity and Total Factor Productivity (TFP). Partial productivity is measured as the ratio of output to a single input. The ratio of output to all inputs combined is the total factor productivity. Generally, two approaches are used in measuring Total Factor Productivity (TFP). These are the growth accounting or index number approach and the econometric or parametric method. The econometric method is based on an econometric estimation of the production function or the underlying cost or profit function [25].

The estimated coefficients of the inputs in the lead equation formed the basis for the analysis of the farmers' allocative efficiency. Allocative efficiency indices $b_{i}$ coefficient was estimated by means of ordinary least squared regressions method. The explicit production function was estimated by

$$
\mathrm{Y}=\mathrm{b}_{0}+\mathrm{b}_{1} \mathrm{x}_{1}+\mathrm{b}_{2} \mathrm{x}_{2}+\mathrm{b}_{3} \mathrm{x}_{3}+\mathrm{b}_{4} \mathrm{X}_{4}+\mathrm{b}_{5} \mathrm{x}_{5}+\mathrm{e}
$$

Where:

$\mathrm{Y}=$ value of cocoyam output ( $), \mathrm{x}_{1}=$ farm size (ha), $\mathrm{x}_{2}=$ labour (manday),

$\mathrm{x}_{3}=$ planting material $(\mathrm{kg}), \mathrm{x}_{4}=$ fertilizer $(\mathrm{kg}), \mathrm{x}_{5}=$ capital $(\#)$

$\mathrm{x}_{1}-\mathrm{x}_{5}=$ coefficient of the parameters to be estimated, while $\mathrm{e}_{1}$ was the error term and $\mathrm{b}_{0}$ was the coefficient.

\section{Materials and Methods}

The South East Nigeria was the main focus. The zone lies between latitude $5^{0} 9^{\prime}$ and $7^{0} 75^{\prime} \mathrm{N}$ of Equator and longitude $6^{0} 85^{\prime}$ and $8^{0} 46^{\prime}$ East of Greenwich Meridian. It has a total land mass of 10,952.400 hectare. The zone has population of 16,381.729 people [26]. The zone is made up of five states viz: Abia, Anambra, Ebonyi, Enugu and Imo States. It lies within the rainforest and derived savanna regions of the country and is bordered in the North by Benue and Kogi States, in the West by Delta and Rivers States, in the South by Akwa Ibom State and in the East by Cross River State. South east states have two major seasons in the year, the rainy season which last from the month of April - October and the dry season that lasts from November to March. The temperature of the area varies from $18^{\circ} \mathrm{C}-34^{\circ} \mathrm{C}$. The inhabitants are agrarian and also engage in non-agricultural activities

A multistage random sampling technique and purposive selection were used to select states, agricultural zones, local government areas, communities and respondents for the study. In stage 1, three out of five states in South East Nigeria were purposely selected because of high intensity of yam production. The selected states were Abia, Anambra, and Enugu (Etim, et al; 2013). Stage 2 involved the purposive selection of two agricultural zones from each state. This gave a total of six agricultural zones. The agricultural zones selected were: Enugu North and Enugu West for Enugu State, Anambra and Aguata zones for Anambra State, and Umuahia and Ohafia Zones for Abia State. In the third stage, two local government areas were purposively selected from each zone based on yam production performance and these brought to a total of twelve Local Government Areas. The local governments areas were Uzo Uwani and Igboeze South local government areas for Enugu North, Awgu and Oji Riverlocal government areas for Enugu West, Anambra East and Anambra West local government areas for Anambra, Orumba North and Orumba South for Aguata, while Ikwuano and Umuahia South for Umuahia. Bende and Isukwuato local government areas were chosen for Ohafia zone.

In the next stage, two communities were purposively selected from each of the twelve local government areas, giving a total of 24 communities. The lists of the yam farmers with the help of agricultural extension agents and local leaders respectively in the communities were obtained to form the sample frame. However, 10 yam farmers were randomly selected from each community. This brought to a total of two hundred and forty farmers for the detailed study. A Structure questionnaire and oral interview were used to collect relevant information as related to the study. The data collected were analysed using gross margin analysis, allocative index and frequency distribution 


\section{Gross margin was used to capture the objective 1}

Gross margin=

(G.M.) $=\mathrm{TR}-\mathrm{TVC}$

i.e. $\mathrm{G} . \mathrm{M}=\sum_{1-1}^{n} P_{1} Q_{1}-\sum_{j-i}^{m} r_{i} x_{i}$

The Net farm income can be calculated by gross margin less fixed input. The net farm income can be expressed as thus:

$$
\mathrm{NFI}=\sum_{1-1}^{n} P_{1} Q_{1}-\left[\left(\sum_{j-i}^{m} r_{i} x_{i}\right)+k\right]
$$

Where: GM = Gross margin ( $),$ NFI = Net farm income ( $), P 1=$ Market (unit) price of output $(\#), \mathrm{Q}=$ Quantity of output $(\mathrm{kg}), \mathrm{ri}=$ Unit price of the variable input $(\mathrm{kg}), \mathrm{xi}=$ quantity of the variable input $(\mathrm{kg}), \mathrm{K}=$ Annual fixed cost (depreciation) $(\AA), i=123 \ldots \mathrm{n}, \mathrm{j}=123$

The $b^{\prime}$ coefficient of the allocative efficiency is determined using multiple regressions analysis. The multiple regression function is explicitly stated as

$$
\mathrm{Y}=\mathrm{b}_{0}+\mathrm{b}_{1} \mathrm{x}_{1}+\mathrm{b}_{2} \mathrm{x}_{2}+\mathrm{b}_{3} \mathrm{x}_{3}+\mathrm{b}_{4} \mathrm{X}_{4}+\mathrm{b}_{5} \mathrm{x}_{5}+\ldots .+\mathrm{bnxn}+\mathrm{e}
$$

Where $Y=$ Yield of the $1^{\text {st }}$ farm in $\mathrm{kg}, \mathrm{X}_{1}=$ Farm size (ha), $\mathrm{X}_{2}=$ Quantity of fertilizer $(\mathrm{kg}), \mathrm{X}_{3}=$ Quantity of seed $(\mathrm{kg}), \mathrm{X}_{4}=$ Labour ( Manday) and $\mathrm{X}_{5}=$ Capital input ( $)$. Four functional forms of the multiple regressions were employed in order to select the one that has provided the best fit. The functional forms tried were:

Linear function

$$
\mathrm{Y}=\mathrm{b}_{0}+\mathrm{b}_{1} \mathrm{x}_{1} \mathrm{~b}_{2} \mathrm{x}_{2}+\mathrm{b}_{3} \mathrm{x}_{3}+\mathrm{b}_{4} \mathrm{x}_{4}+\mathrm{b}_{5} \mathrm{x}_{5}+\mathrm{ei}
$$

Double log function:-

$$
\ln (\mathrm{y})=\ln \mathrm{b}_{0}+\mathrm{b}_{1} \ln \mathrm{x}_{1}+\mathrm{b}_{2} \ln \mathrm{x}_{2}+\mathrm{b}_{3} \ln \mathrm{x}_{3}+\mathrm{b}_{4} \ln \mathrm{x}_{4}+\mathrm{b}_{5} \ln \mathrm{x}_{5}+\mathrm{ei}
$$

Semi log

$$
\mathrm{Y}=\ln \mathrm{b}_{0}+\mathrm{b}_{1} \ln \mathrm{x}_{1}+\mathrm{b}_{2} \ln \mathrm{x}_{2}+\mathrm{b}_{3} \ln \mathrm{x}_{3}+\mathrm{b}_{4} \ln \mathrm{x}_{4}+\mathrm{b}_{5} \ln \mathrm{x}_{5}+\mathrm{ei}
$$

Exponential function

$$
\ln Y=b_{0}+b_{1} x_{1}+b_{2} x_{2}+b_{3} x_{3}+b_{4} x_{4}+b_{5} x_{5}+e i
$$

The choice of the best functional form was based on the magnitude of the $\mathrm{R}^{2}$ value, the high number of significance, size and signs of the regression coefficients as they conform to apriori expectation.

The four functional forms of equation (1) were tried and the best fit chosen as lead equation. The estimated coefficient of the inputs of the lead equation form the basis for the analysis of farmers' allocative efficiency.

Allocative efficiency is determined by equating the marginal value product of a resource to its unit price. That is;

$$
\text { MVpi }=\mathrm{p}_{\mathrm{y}} \mathrm{f}_{\mathrm{i}}=\mathrm{Px}_{\mathrm{i}}
$$

MVP $=$ Marginal value product of ${ }_{i}^{\text {th }}$ resource, $\mathrm{P}_{\mathrm{y}}=$ price of unit of output 
$F_{i}=\frac{d_{y}}{d x_{i}}$ is the marginal physical production of $\mathrm{i}_{\mathrm{i}}^{\text {th }}$ resource, $\mathrm{Px}_{\mathrm{i}}=\mathrm{is}$ the unit of the ${ }_{\mathrm{i}}^{\text {th }}$ resource.

$\mathrm{Px}_{\mathrm{i}}=$ is the unit price of ${ }_{\mathrm{i}}^{\text {th }}$ resource. The allocative index for each resource is derived as follows;

$$
\mathrm{k}_{\mathrm{i}}=\mathrm{MVP} / \mathrm{P}_{\mathrm{i}}=\mathrm{P}_{\mathrm{y}} \mathrm{f}_{\mathrm{i}} / \mathrm{P}_{\mathrm{i}}
$$

where $\mathrm{k}_{\mathrm{i}}=$ allocative efficiency index and other terms were previously defined.

If $r=1$, it implies that resources are efficiently utilized i.e. MVP $=$ MFC $=1 \mathrm{r}>1$, implied that resources are underutilized, $\mathrm{r}<1$, implied that resources are over utilized (Nwosu and Okoli, 2010). The objective 3 was captured using descriptive statistics such as percentage responses frequency distribution.

\section{Results and Discussion}

The costs and return of yam production per hectare by farmers in south east Nigeria are presented in Table 1.

Table 1: Costs and Return on Yam Production Per Hectare

\begin{tabular}{|c|c|c|c|c|}
\hline Item & Unit & Quantity & $\begin{array}{c}\text { Price/ } \\
\text { Cost/Unit } \\
( \pm) \\
\end{array}$ & $\begin{array}{c}\text { Cost/Value } \\
\text { ( })\end{array}$ \\
\hline \multicolumn{5}{|l|}{ Gross revenue } \\
\hline Yield & $\mathrm{Kg}$ & 10,000 & 450 & $4,500,000$ \\
\hline \multicolumn{5}{|l|}{ Physical input cost } \\
\hline Yam sett & $\mathrm{Kg}$ & 10,000 & 150 & 1,500000 \\
\hline Fertilizer (NPK) & $\mathrm{Kg}$ & 350 & 6,000 & 42,000 \\
\hline $\begin{array}{l}\text { Transportation and other } \\
\text { miscellaneous }\end{array}$ & & & & 35,000 \\
\hline Total & & & & $1,577,000$ \\
\hline \multicolumn{5}{|l|}{ Labour } \\
\hline $\begin{array}{l}\text { Land preparation (clearing } \\
\text { and mounding) }\end{array}$ & Man-day & 20 & 2,500 & 50,000 \\
\hline \multicolumn{5}{|l|}{ Yam sett preparation and } \\
\hline Planting & Man-day & 5 & 1200 & 4,800 \\
\hline Fertilizer application & Man-day & 7 & 1200 & 8500 \\
\hline Hand weeding & Man-day & 13 & 1,200 & 15,600 \\
\hline Harvesting & Man-day & 10 & 1200 & 12000 \\
\hline Total labour cost & & & & 90,900 \\
\hline Total variable cost & & & & 1667900 \\
\hline \multicolumn{5}{|l|}{ Opportunity cost of capital at } \\
\hline bank lending rate of $23 \%$ & & & & 383617 \\
\hline Total variable cost & & & & 2051517 \\
\hline Gross margin (GM) & & & & 2448483 \\
\hline \multicolumn{5}{|l|}{ (TR-TVC) } \\
\hline $\begin{array}{l}\text { Depreciation of fixed assets } \\
\text { excluding land }\end{array}$ & & & & 6,200 \\
\hline Total cost (TVC+TFC) & & & & 2454683 \\
\hline Farm income (TR-TC) & & & & 2045317 \\
\hline Benefit cost ratio & & & & $1: 1.83$ \\
\hline
\end{tabular}

Source: Field Survey, 2016 
The physical input used yam production as contained in Table 1 included yam setts, fertilizer (NPK), transportation and other miscellaneous. Among all the physical inputs, the cost of yam setts $(\$ 1,500,000)$ constituted the highest proportion, constituting about $95.1 \%$ of total physical input. This could be related to the fact that the same edible portion is used as planting material [27]. The miscellaneous and transportation $(\$ 35,000)$ was the least. The total cost of the physical input was $\$ 1,577,000$.

Among the labour items considered in Table 4, cost of labour for land preparation $(\$ 50,000)$ was highest. This could be associated to the fact that land preparation in traditional farming system is tedious as the operation is not mechanised, hence, commands highest labour cost among other farming activities to accomplish [25]. This finding agreed with [11]. The least cost of labour incurred by farmers in yam production was cost of yam sett preparation and planting $(\$ 4,800)$. The total number of man days of labour employed in yam production in the study area were 55 , costing about $\$ 90,900$.

The Table further reveals that the total revenue was $\$ 4,500,000$ with the total cost of $\$ 4$, 418300 , and the difference which is gross margin was $\$ 431392$. The average net profit for yam farmers per hectare was $\$ 2,045,317$ with benefit cost ratio of 1:1.83. The production of yam in study area was profitable since total revenue was greater than total cost of production.

Table 2 reveals that the result of the Double log functional form was chosen as lead equation based on econometric and statistical criteria.

Table 2: Result of Allocative Efficiency of Yam Production

\begin{tabular}{|l|c|c|c|c|}
\hline Variable & Linear & Double log & Expon. & Semi -Log \\
\hline Constant & $\begin{array}{c}8.681 \\
(3.040)^{* * *}\end{array}$ & $\begin{array}{c}4.001 \\
(3.111)^{* * *}\end{array}$ & $\begin{array}{c}7.981 \\
(4.210)^{* * *}\end{array}$ & $\begin{array}{c}6.881 \\
(3.981)^{* * *}\end{array}$ \\
\hline Fertilizer & 0.810 & 1.254 & 0.0003 & 2.172 \\
& $(0.125)$ & $(2.091)^{* *}$ & $(0.727$ & $(1.302)$ \\
\hline Farm Size & 0.526 & 1,727 & 2.041 & 0.427 \\
& $(1.067)^{*}$ & $(0.007)$ & $(0.071)$ & $(0.117)$ \\
\hline Labour & 2.670 & 0.898 & $2 . .081$ & 0.4552 \\
& $(0.421)$ & $(3.04)^{* * *}$ & $(0.071)$ & $(2.007)$ \\
\hline Planting & 0.007 & 1.742 & 0.092 & 1.424 \\
Material & $(0.421)$ & $(0.720)$ & $(3.072)$ & $(0.333)$ \\
\hline Capital & 0.745 & 0.008 & 0.920 & 2.728 \\
& $(0.209)$ & $(0.244)$ & $(0.112)$ & $(0.085)$ \\
\hline $\mathrm{R}^{2}$ & 0.627 & 0.790 & 0.524 & 0.602 \\
\hline F ratio & 2.421 & 0.598 & 0.402 & 0.454 \\
\hline
\end{tabular}

Source: Filed Survey, 2016

$*, * *, * * *$ Significant at $1 \%, 5 \%$ and $10 \%$ respectively.

Its coefficient of multiple determination $\left(\mathrm{R}^{2}\right)$ was 0.79 , indicating that $79 \%$ of the variation in the output of yam were accounted for by the variable inputs included in the model, while the remaining $21 \%$ were due to error term. The coefficient of fertilizer was negative and significant at $5 \%$ alpha level. The negative sign of the coefficient could be linked to partly to its high cost at farm level and consequently, most poor resource farmers are denied the opportunity of using it [28]. The statistical test of the coefficient of labour was positive and significant at $1 \%$ probability level. This finding agrees with [9], who opined that labour cost contributes to more than $45 \%$ of the total cost of yam production and to cushion the effect, most household farmers resort to use of family labour. Farm size coefficient was positive and significant at $10 \%$ alpha level. [29] reported that in many developing countries, farmers operate in fragmented land and thus could be an obstacle to agricultural mechanization and modernization 
Table 3 reveals that yam farmers did not achieve absolute allocative efficiency in the use of any of the yam productive resource, since the allocative efficiency indices of the productive resource are below 1 .

Table 3: Distribution of Allocative Indices of Yam Farmers

\begin{tabular}{|l|c|c|c|c|}
\hline Variable & MVP & MFC & R & D \% \\
\hline Farm Land & $76,490.00$ & 13,650 & 5.603 & 82.2 \\
& & & & \\
\hline Planting Material & 2,456 & 120 & 20.467 & 95.1 \\
\hline Fertilizer & 26400 & 6000 & 4.410 & 77.3 \\
\hline Labour & 953 & 1200 & 0.794 & 25.9 \\
\hline Stakes & 568 & 629 & 0,963 & 10.6 \\
\hline
\end{tabular}

Source; Field, Survey, 2016

However, the results show that the farmers under - utilized resources of stakes and labour, while fertilizer, farm land and planting material (seed yam) were over utilised. The over-utilization of resource implied that less of the profit maximization of the resource was used [30, 31]. In a related study, the finding of [15] concurred with the assertion in this study that none of the sampled farmers achieved optimum use of the resources used, as they either underutilised or over utilised the resources considered.

The arbitrary dumping of organic manures in farms around households' residences could be the likely reason for the over utilization of the resource of fertilizer, while the limited use of hired labour by poor resource household farmers, perhaps as result of high cost could be linked to the under- utilization of the resource [25]. To achieve absolute allocative efficiency and hence, maximum profit, yam farmers should adopt production technique that will increase their use of farm land by $82.2 \%$, planting material $(95.1 \%)$ and fertilizer $(77.3 \%)$, while reducing stakes and labour by $10.7 . \%$ and $25.9 \%$ respectively. The low resource endowment of most of our farmers could be because of their poor financial base, hence, resulting in under-utilization of resources. The effects of under-utilization of resources are that farming remains in rudimentary and traditional levels in most developing countries $[32 ; 33]$.

The elasticity of production shows the change in output relative to unit change in input [30] and shows in Table 4

Table 4: Elasticity of Production and Return to Scale of yam

\begin{tabular}{|l|c|}
\hline \multicolumn{1}{|c|}{ Variable } & Elasticity of Production \\
\hline Farm size & 1.727 \\
\hline Planting materials & 1.742 \\
\hline Fertilizer & 1.524 \\
\hline Labour & 0.898 \\
\hline Stakes & 0.0080 \\
\hline Return to Scale & 5.899 \\
\hline
\end{tabular}

Source; Field Survey; 2016

The elasticity of production of yam was estimated directly from Cobb Douglas coefficients. The value of the return to scale of yam production in South - East, Nigeria as shown in table 4 was 5.889. This is found to be greater than unity, indicating increasing return to scale. Hence, the yam farmers in the study area were said to be operating in stage 1 (irrational stage) of production. The implication is that yam farmers in the study area were not yet operating at optimum scale of production. Therefore, hence, there is need for improvement such as using more variable inputs to boost yam production. This finding concurred with [20] who posited that the actual cases of increasing returns occurred relatively to low level of output that characterised small scale farming. Furthermore, the above scenario implies that when all factor inputs were varied by $1 \%$, the responsiveness of yam output to such input variation would be $5.889 \%$. 
Table 4 further shows that the production elasticity of less than one for labour (0.898) and stakes $(0.0080)$ used in the production, indicates that the factor inputs and yam output had inelastic relationship and consequently their over-utilization resulted. However, for the other inputs (fertilizer, farm size and planting material) whose production elasticity were greater than 1 had elastic relationship with yam output, thus considered to be under - utilized.

The effects of yam production activities to the environment is shown in Table 5

Table 5: Effects of Yam Production Activities to the Environment

\begin{tabular}{|c|c|c|c|}
\hline Activities & Frequency & Percentage & Ranking \\
\hline \multicolumn{4}{|l|}{ Clearing } \\
\hline Wild Life habitation & 189 & 78.75 & $7^{\text {th }}$ \\
\hline Oxygen - carbon dioxide balance & 169 & 70.4 & $9 \mathrm{~h}$ \\
\hline Erosion & 200 & 83.3 & $5^{\text {th }}$ \\
\hline Effects wild fruits and vegetable & 160 & 66.7 & $10^{\text {th }}$ \\
\hline \multicolumn{4}{|l|}{ Burning } \\
\hline Effect aesthetic & 175 & 72.9 & $9^{\text {th }}$ \\
\hline Causes erosion & 109 & 45.4 & $17^{\text {th }}$ \\
\hline Increases soil temperature & 201 & 83.75 & $4^{\text {th }}$ \\
\hline Reduction of soil nutrient & 195 & 81.25 & $6^{\text {th }}$ \\
\hline Soil water & 108 & 45 & 18 \\
\hline Air & 122 & 50.83 & $15^{\text {th }}$ \\
\hline Human health and welfare & 213 & 88.75 & $1^{\text {st }}$ \\
\hline Organic nitrogen into mobile nitrates & 114 & 47.5 & $16^{\text {th }}$ \\
\hline Regeneration of trees & 129 & 53.75 & $13^{\text {th }}$ \\
\hline Effect on vegetation & 109 & 45.4 & $17^{\text {th }}$ \\
\hline Soil & 145 & 60.4 & $12^{\text {th }}$ \\
\hline \multicolumn{4}{|l|}{ Pesticides Use } \\
\hline Human health & 209 & 87.08 & $2^{\text {nd }}$ \\
\hline Aquaculture & 200 & 83.3 & $5^{\text {th }}$ \\
\hline Birds & 139 & 57.9 & $12^{\text {th }}$ \\
\hline Pest resistant & 89 & 37.08 & $22^{\text {nd }}$ \\
\hline Effect on soil fertility & 129 & 53.75 & $13^{\text {th }}$ \\
\hline Water pollution & 114 & 47.5 & $16^{\text {th }}$ \\
\hline Air pollution & 106 & 44.17 & $19^{\text {th }}$ \\
\hline Soil & 209 & 87.08 & $2^{\text {nd }}$ \\
\hline Food poison & 125 & 52.08 & $14^{\text {th }}$ \\
\hline \multicolumn{4}{|l|}{ Fertilizer= In organic Fertilizer } \\
\hline Global warming & 87 & 36.25 & $23^{\text {rd }}$ \\
\hline Methemoglobinemia & 101 & 42.08 & $21^{\text {st }}$ \\
\hline Eutrophication & 98 & 40.83 & $20^{\text {th }}$ \\
\hline Affect Agricultural productivity & 123 & 51.25 & $15^{\text {th }}$ \\
\hline Acidic Rain & 98 & 40.83 & $20^{\text {th }}$ \\
\hline \multicolumn{4}{|l|}{ Organic Fertilizer } \\
\hline Proliferation of environment & 203 & 84.58 & $3^{\text {rd }}$ \\
\hline Air pollution & 158 & 65.83 & $11^{\text {th }}$ \\
\hline Water pollution & 129 & 53.75 & $13^{\text {th }}$ \\
\hline \multicolumn{4}{|l|}{ Tillage } \\
\hline Soil quality & 201 & 83.75 & $4^{\text {th }}$ \\
\hline Increase in residues & 183 & 76.25 & $8^{\text {th }}$ \\
\hline
\end{tabular}

*Multiple Responses

Source; Field Survey; 2016 
About $78.75 \%$ of the respondents complained that clearing for yam production in the forest areas could result in destruction of wild life homes. This situation could lead to posing farmers and their farms to risk of being attacked by the animals that are lead astray, thus affecting the farmers' production and productivity [34]. The finding of [35] concurred to the above assertion.

More so, $70.4 \%$ of the farmers studied posited that clearing particularly those involved in felling of the tree, which could affect the cooling effect associated with vegetation. [36] made similar assertion. They stated that trees help in ensuring oxygen - carbon dioxide exchange, leading to cooling effect of the environment. As well, $83.3 \%$ of the farmers sampled reported problem of erosion as result of bushing clearing for yam cultivation. The cutting of trees and as well clearing of grasses especially in erosion prone areas could predispose land to wind and water erosions [34]. Furthermore, the nearly extinction of wild fruits and vegetable could partly associated with clearing of bushes and forestry in bid for agricultural intensification. This activity has denied mankind especially in developing countries access to organic vegetables and fruits that are universal recommended for healthy living [37]. About $66.7 \%$ of the respondents complained on the poor access to wide vegetables and fruit as result of land clearing.

Furthermore, $72.9 \%$ of the farmers studied were of the view that burning has impact of aesthetics of the affected area. [35] opined that the more instantaneous adverse effect included smoke and ash, top killed understory plants, and a blackened farm floor, which has aim of achieving increased visual variety and increased visual penetration. Moreover, $45.4 \%$ of the sample farmers complained that burning could cause loss of soil moisture. [34] revealed that the more the loss of shade provided by the trees in the land through burning, the more odds of loss of soil water through evaporation. Also, bush burning can cause the soil to lose its ability to absorb and retain water, makes top layer of soil to be water repellent and plant roots no longer pull moisture into the soil [38]. Also, $45.4 \%$ of the respondents reported the problem of erosion. The erosion of the soil could be related to loss of root systems and soil water repellency as result of burning [35]. Besides, $83.75 \%$ of the sampled population reported the problem of high soil temperature through bush burning, soil surface are left bare, leading to increase in soil temperature as the sun intensity increases. Burning bushes exposes the soil to the sun. The finding of [36] concurred to the assertion. They posited that high soil temperature could deter seed germination and hampers the activities of microbes that enhance soil fertility. As well, $47.5 \%$ of the sampled population reported on the conversion of organic nitrogen into mobile nitrates through burning. The mobile nitrates is the form plants can easily absorbed for use and this accounts for the abrupt plant growth that emerges after fire burning [37]. The finding of [38] was synonymous with above statement. They reasoned that mobile nitrates are more vulnerable to water runoff and long-term bush burning leads to nitrogen free soil.

Still, the increase in regeneration of certain trees could be attributed to burning as observed by $53.75 \%$ of the respondents. The finding of [34] concurred to the assertion. They opted that recent research has shown that fire could be imperative for the regeneration of certain species of upland oaks. The negative effect of burning on soil was observed by $60.4 \%$ of the sampled farmers in the study area. The effects of burning on soil could differ significantly depending on the frequency, duration, and intensity of fire, as well as soil characteristics. However, prescribed burning could impact not significant damages compared to burning of piled or windrowed debris, or burning when fuel and/or soil moisture conditions are extremely low may perhaps raise temperatures long to light soil organic matter, alter the structure of mineral soil and also change the clay soil structure [39]. The work of [40] reported similarly to the above declaration. They revealed that prescribed fire might influence soil amenities and as well curtail the valuable effects of the fertilizer to the crop. Furthermore, bush burning enhances the soil's $\mathrm{pH}$ and this situation is solemnly in ecosystems that thrives on low $\mathrm{pH}$ values, and inhabitant vegetation that takes time in launch itself once more [37]. Also $81.25 \%$ of the sampled population reported on the important of burning in making available of soil nutrients to the plants. [39] reported that burning could help in enhancing soil nutrient through increasing nitrogen fixation in the soil and thereby recompense for nitrogen loss to the atmosphere due to burning of the litter layer. Furthermore, trees consume and confiscate lots of soil 
nutrients, and these nutrients can only be made available to the soil for use by other plants only such plant dies and decompose. The processes of the decomposition and release of the nutrients takes time, but slight burning might speeding up the processes [39]. Additionally, $45.5 \%$ of the respondents reported that burning effects the vegetations through killing or damaging plants in the farm. The extent of the harms of the burning to the plants depends on among others air temperature, , intensity of the fire, duration of exposure to high temperature emanating from the fire, the plant bark thickness and stem diameter [37]. Still, 45\% of the farmers observed effect of burning on water quality. [40] opted on the import of burning in enhancing the rate of runoff and this (run off) is capable of contaminating water quality in the streams and lakes especially in the low land areas from upland areas with debris (soil particles, dissolved inorganic and other materials)

As well, $50.83 \%$ of the respondents complained about air pollution as result of burning. Literatures show that burning causes lots of air pollution with smokes that contains particulate of ash, partially burnt fuel, liquid droplets and invisible gases (carbon monoxide, carbon dioxide, hydrocarbons, and small quantities of nitrogen oxides) [40]. The amount of particulate in the smoke as asserted by [39] is a function of the quantity and nature of fuel burnt, fuel moisture content, rate of fire spread and type of firing method used. Rate of smoke diffusion could be correlated to the atmospheric stability and wind speed [38]. As well, recent research shows that when noxious plants such as poison ivy burn, the smoke can cause skin rashes [41]. More so, $88.75 \%$ of the respondents encountered human health and welfare challenges as result of burning. The exposure of people to smoke from burning may lead to incontinences and eye and respiratory system irritations. These effects are more severe with people with respiratory illnesses or near health-care facilities [34]. However, smokes with high concentrations of carbon monoxide as observed by [41] may possibly lead to impaired alertness and judgment to man.

More so, $87.07 \%$ of the sampled farmers complained about pesticides effects to human health. [42] and [43] reported similarly. They opined that pesticides toxicity by man through ingestion, contact and inhalation might result to various forms of diverse of metabolic and systemic dysfunctions, psychological, neurological, cardio respiratory and gastrointestinal symptoms coupled with low plasma, ECG, the serum LDH levels, and cholinesterase (ChE) activities and in most cases outright pathological conditions. Further, $83.3 \%$ of the sampled population reported the negative effect of pesticides on aquaculture. Pesticides kill fish and reduced their productivity, when it (pesticides) contaminate its abode, water bodies. The effect of pesticides is more severe during the dry season, because during this time the dilution capacity of the water systems is low, thus escalating the risk of high concentrations of toxic chemicals [42]. Also, [43] opted that dry season is the crucial time for aquatic animals, as they undergo stress from natural mortality and high fishing pressure by man. In addition, there are problems of bird extermination and reproductive failure in birds as result of pesticides [44]. About, $57.9 \%$ of the farmers sampled attested to the above affirmation. Besides, $37.08 \%$ of the sampled population reported problem of development of resistant pests. Literatures show that the long use of persistent pesticides like DDT produces pesticide - resistant pests which will produce progenies requiring higher doses of pesticides for their eradication [45]. As well, pesticides such as 2,4-D and triclopyr, when misused could result in lowering soil fertility through depopulating the beneficial soil microorganisms (nitrogen-fixing blue-green algae, mycorrhizal fungi etc) that aid in enhance fertility- status of the soil [46, 44]. The problem of poor soil fertility as result of pesticides misuse was reported by $53.75 \%$ of the respondents

Still, food poisoning: problem through pesticides contamination was encountered by $52.08 \%$ of the farmers interviewed in the study area. Literatures revealed that most victims of pesticides food poison might be as result of none or partial washing of agricultural produce that were treated with chemicals before consumption. As well, eating grains, vegetables and fruits whose the residual effects of the chemical used for treating them have not expired might lead to pesticide poison [45]. Water pollution furthermore was observed by $47.5 \%$ of the farmers studied in the study area. The non adherence to minimum allowable distance between water bodies and spray area, disposal 
abuses as well as runoffs from farms (especially on vegetable and rice farms which are close to water bodies) [47]. What's more, $44.17 \%$ of the respondents remonstrated about air pollution; Pesticide drift especially when sprayed in windy period and in the direction of wind, the pesticides particles mighty be carried by wind to other areas, potentially contaminating there [48].

As well, use of organic fertilizer in yam production particularly may possibly cause air pollution, as reported by $65.83 \%$ of the total respondents. The use of organic fertilizer in form of poultry pig, cow dung and farm yarm yard manures in farming has the features of polluting the environments with odour, which could be source of annoyance to the people the passerby and residents in the area [49]. To avoid pollution of the environment with such odour, the of proper incorporation of manures in the farm with the soil. Moreover, $84.58 \%$ of the farmers complained about proliferation of the environment with rats mosquito and other rodents in the environment. The rats and other rodents could constitute a nuisance to man effects [50]. Furthermore, the manures if not incorporated into the soil and in moist condition, could lead to breeding of mosquitoes, resulting to malaria [51]. Moreover, 53.75\% of the respondents encountered the problem of water pollution as result of use of organic fertilizer. The water pollution problem could be as result of possible seepage into the ground water during rainy day of the organic manure leading to colourisation and smelling of the water bodies [52]. However, 83.75\% of the respondents reported on the negative effect of tillage to soil quality. [56] revealed that tillage fractures the soil, disturb soil structure, accelerating surface runoff and soil erosion. As well, 76.25\% observed that much tillage could lead to reduced crop residue. Crop residue helps to cushion the force of hammering raindrops and if the absence of crop residue, soil particles might be displaced effortlessly and moved away. The splashed soil particles obstruct the soil pores, thus closing up the soil's surface, leading to reduced water penetration [53].

The constraints to yam production as shows in Table 5 reveals that poor access to credit $(91.7 \%)$ was the highest constraint confronting adequate yam production in the study area.

Table 6: Constraints to Yam Production

\begin{tabular}{|l|c|c|}
\hline \multicolumn{1}{|c|}{ Variable } & Frequency & Percentage \\
\hline Poor access to credit & 220 & 91.7 \\
\hline High cost of pesticides & 210 & 87.5 \\
\hline Poor access to extension services & 200 & 83.3 \\
\hline High cost of Labour & 198 & 82.5 \\
\hline High cost of fertilizer & 186 & 77.5 \\
\hline Soil fertility & 82 & 34.2 \\
\hline Theft & 80 & 33.3 \\
\hline
\end{tabular}

Source; Field Survey; 2016

*Multiple Response

This agrees with the finding of [28], who opined that the location of banks in urban areas and high interest rate a charged by lending agencies in the country could be the reasons for rural farmers' poor access to credit. [54] opined that agricultural credit has the potential in enhancing efficient resource allocation, permits application of technology, reduces post harvest wastes and stabilizes farm input prices, farm income and enhance efficient marketing of agricultural products. Furthermore, high cost of pesticide $(87.5 \%)$ was complained by most of the respondents to yam production in the study area. Studies infer that farmers sparsely use pesticides because of its high cost and adulteration. As result, many of the famers use Indigenous known Technology (IKT) which often has the problems of low efficacy, consequently losses of agricultural produce [33, 55]. As well, $82.5 \%$ of the respondents complained about high and scarcity of labour at farm level as a limiting factor to yam production in the study area. The urban migration of able- bodied youths in search of white collar jobs, while few of them that stayed behind charges more to meet with urban counterpart can be cited to be responsible for the high cost of the resource [13]. Moreover, $83.5 \%$ of the sampled farmers encountered the problem of poor access to extension services. Several literatures opined on the importance of extension services in information dissemination on the mode 
of applications or usages of technologies as well as the availability of the technological inputs $[25,56,57]$. Therefore, there is need for frequent extension contact, as it could likely help to minimize doubts among farmers, ensure timely procurement of inputs and encourage sustained usage of the improved technologies [58, 59]. More-so, unavailability and high cost of fertilizer was reported by $77.5 \%$ of the total respondents as hindrance to yam production in the study area. Fertilizer particularly inorganic fertilizer is expensive and not readily available at farm level for the farmers' use, resulting in low production and productivity [50]. The finding is in agreement with [60] and [29], who reported that high cost and untimely availability of fertilizer have resulted in low agricultural productivity which is an important contributor to poverty persistence especially in most rural areas in the sub- Saharan Africa that are agrarians.

\section{Conclusion and Recommendations}

The major conclusion drawn from this study was that fertilizer, farm size and labour were major determinants of yam production in the study area. Also, yam is a profitable enterprise in the study area. Furthermore, yam production activities in form of clearing, burning, pesticides use, fertilizer use and tillage could result in among others wild Life habitation, oxygen - carbon dioxide balance, erosion, effect aesthetic, increases soil temperature, reduction of soil nutrient, human health and welfare, organic nitrogen into mobile nitrates, regeneration of trees, effect on vegetation, human health, aquaculture, effect on soil fertility and water pollution

More so, it's production was constrained by poor access to credit, high cost of labour, high cost of pesticides and poor access to extension services. The following recommendations were made:

(1) Policies that will enable farmers to have access to fertilizer at reduced cost and at the right time should be encouraged. The federal government fertilizer subsidy policy should be revisited and restructured to ensure that genuine farmers benefits most

(2) Farmers should be provided with loan through microfinance and commercial banks at a low interest rate and affordable collaterals;

(3) Extension agent performance could be enhanced through provision of adequate motivation in form of payment of over time allowances, salaries and other incentives at the appropriate time.

(4) In view of that fact that most production inputs were under-utilized, hence to achieve optimum or absolute allocative efficiency and hence, maximum profit, the farmers should be encouraged to increase the use of those under-utilized resources. This can be achieved through appropriate policies that would enhance their access to these production inputs. More so, there is need to encourage the reallocation and redistribution of farm inputs.

(5) The introduction of new, less toxic chemicals could help reduce the risks to yam farming household in particular.

(6) The need for government agencies concerned to introduce health education programs on economics pesticides use by farmers particularly yam producing farmers in order to lessen pesticides toxicity by farmers is very crucial.

(7) The need for sensitization on the use of personal protective equipment by yam farmers by government agencies concerned and nongovernmental organization to curtail maximal pesticides toxicity is very important.

(8) The need to organize seminars, workshops and conferences on environmental pollution through use of poultry manure and chemical fertilizer as soil amendment and consequences of the misuse by government agencies concerned and other private sectors is very imperative.

(9) Extension agents should be encouraged to perform their duties of disseminating information on dangers of fertilizer abuse and technical assistance on best approaches to apply fertilizer by farmers without endangering the environment. 
(10) Avoid burning in soils that are very prone to erosion

(11) During prescribed burning, the need for soil to be damp is very crucial in order to avoid the burning of the humus soil and an organic layer. Damp soil also aids mop up after the burn.

(12) Adequate wind presence could facilitate in disperse the heat and slow its rise to avoid damaging the trees in the bush or farm.

(13) The urgent need to develop through research and disseminate to farmers labour saving device such as hand driven plough in order to facilitate in incooperating poultry manure into the soil to reduce odour, flies and other environmental nuisances emanating from exposing poultry manure to the environment.

(14) Construction of fire breaks must be done in accordance with best management practice for water quality to avoid soil erosion and water quality problems.

(15) The wrong practice of ring firing a burn area could lead to entrapment of animals and consequently death. Therefore, the need for prescribed burning from one side of the land so that animals could escape from other sides should be encouraged.

\section{References}

[1] International Institute for Tropical Agriculture (IITA). Strategic plan for yam: 1989-2010. Ibadan, Nigeria.2011; Pp 133

[2] National Root Crop Research Institute (NRCRI.).Annual report of National Root Crop Research Institute, Umudike, Umuahia.2013;38p.

[3] D.B, Zaknayiba. and L. Tanko, L. Costs and returns analysis of yam production among small scale farmers in Karu local government area, Nasarawa State, Nigeria. PAT; 2013;9(1): 7380.

[4] FAO: FAOSTAT: Food and agriculture. Database result.2008.

[5] FAO . Food and agriculture organization production year book. Rome, Italy.2012

[6] FAO. FAOSTAT Statistics division of the food and agriculture organization. http://faostat.fao.org/site/567/desktopdefaultaspx? Accessed July 03. Data base results.2013

[7] J P. Migap and J S. Audu. Empirical study on yam cultivation and economic development of Taraba State: Case study of Wukari local government area. Journal of Business and Organizational Development. 2012; 4: 32-52.

[8] FAO FAOSTAT, statistics division of the food and agriculture organization. http://faostat.fao.org/site/567/desktopdefaultaspx? Accessed July 03, 2008, Data base results. 2013

[9] F I. Nweke, B O. Ugwu and CIA. Asadu : Production costs in the yam based cropping systems of south Eastern, Nigeria. Research monograph, No 6, IITA, Ibadan Nigeria;2009; Pp 29.

[10] J C Nwaru. Rural credit market and resource use in arable crop production efficiency in Imo State of Nigeria. Ph.D Thesis, Michael Okpara University of Agriculture, Umudike Abia State.2004; $24 \mathrm{p}$

[11] E S. Okeoghene, J. Egbodion and O.O.Ose,. Profitability Analysis of Yam Production in Ika South local government area of Delta State, Nigeria. Journal of Biology, Agriculture and Healthcare. 2O13; 3(2): 118-130.

[12] D O. Ohajianya;. Comparative analysis of organic and inorganic fertilizer use in cassava production in Imo State, International Journal of Agriculture and Rural Development, 2007; 9: 30-34 http://dx.doi.org/10.4314/ijard.v9i1.2660

[13] S.I.Ume and A.I.N. Kaine. Determinants of cocoyam farmers' choice of adaptation methods to climate change in South-East, Nigeria, Journal of Agriculture and Food Environment. 2017;4(2) 23-35.

[14] FAO. Food and agriculture organization production year book. Rome, Italy.2006. 
[15] C.S Nwosu and V B N. Okoli. Economic analysis of resource use by ware yam farmers in Owerri Agricultural Zone of Imo State, Nigeria. Proceedings of the $44^{\text {th }}$ Annual Conference of Agricultural Society of Nigeria held at Tadoke Akintola University of Technology Ogbomoso, Oyo State Nigeria. 2010;Pp.29-34..

[16] CYG.Amankwah. The structure and efficiency in resource use in maize production in the Asamankese District of Ghana. Doctoral dissertation,University of Ghana. 1996; Pp. 41-45

[17] M U Awoke, M.U Resource use efficiency in multiple cropping system by small-holder farmers in Ebonyi state of Nigeria". A Ph.D. thesis of Department of Agricultural Economics and Extension of Enugu state University of Science and Technology. 2001; Pp. $34-42$.

[18] N A.Etim, D Thompson and C E Onyenweaku. Measuring efficiency of yam (Dioscorea spp.) production among resource poor farmers in rural Nigeria. Journal of Agriculture and Food Sciences,.2013; 1(3): 42-47.

[19] M A.Maikasuwa and A L.Ala. Determination of profitability and resource-use efficiency of yam production by women in Bosso local government area of Niger State, Nigeria. European Scientific Journal.2013; 9(16): 196-205.

[20] S C Kumbyakiar.A generalized production frontier approach for estimating determinants of inefficiency in U. S dairy farms. Journal of Business Economics and Statistics. 2006; 9:279281.

[21] G. Danso-Abbeam, AM. Dahamani and G. Bawa. Resource-use-efficiency among smallholder groundnut farmers in Northern Region, Ghana. Am. Exp. Agric. 2012; 6(5):290.

[22] M LJhingan, M.L.Micro Economic Theory (6th Edition). India, Vrinda Publications Ltd.; 2007; 56P

[23] M. Fargnoli, M. Lombardi, D; Puri, L. Casori, E Masciarelli, S.Mandic-Rajcevic and C. Colosio. The Safe Use of Pesticides: A Risk Assessment Procedure for the Enhancement of Occupational Health and Safety (OHS) Management. Int. J. Environ. Res. Public Health.2009; 16, 310.

[24] FAO. Food crop and storage, corporate document repository and databases. 2008.

[25] S. I.Ume, C I, Ezeano L U, Agu, and J.Emma-Ajah J Resource. Use Efficiency among Cocoyam Farmers in Anambra State of Nigeria. Asian Research Journal of Arts \& Social Sciences. 2016 1(3): 1-11.

[26] National Population Commission (NPC). Population census of Federal Republic of Nigeria: Analytical report at the national level. National Population Commission, Abuja.2006.

[27] C S.Nwosu, and VBN Okoli. Economic analysis of resource use by ware yam farmers in Owerri Agricultural Zone of Imo State, Nigeria. Proceedings of the $44^{\text {th }}$ Annual Conference of Agricultural Society of Nigeria held at ladoke Akintola University of Technology Ogbomoso, Oyo State Nigeria, 2010;pp.29-34.

[28] S. I.Ume, C.I. Arene and B.Okpukpara Adoption of improved crop production technology in Anambra State, Nigeria: T \& V system approach. Farm ManagemenT.Association of Nigeria, $20^{\text {th }}$ Annual National Conference held at Jos.2010; Pp; $322-330$

[29] C. E.Onyenweaku, B.C Okoye and K.C Okorie. Determinants of fertilizer adoption by rice farmers in Bende Local Government Area of Abia State, Nigeria. Nigeria. Agricultural Journa.2010; 41(2): 1-6.

[30] J.A Mbanasor, and I. O.Obiora, I. O. Resource productivity under Fadamas cropping system in Umuahia North Local Government Area of Abia State, Nigeria. Journal of Tropical and Subtropical , 2013;6; $23-29$

[31] G. I. Wilcox,C O A Ugwumba, A.I, Achike C.Agbagwa and F.B Uche F.B.Allocative efficiency of smallholder cocoyam farmers in South-South, Nigeria International Journal of Environment, Agriculture and Biotechnology (IJEAB)2016;4(1)4; $24-28$.

[32] S.A.Omoruyi, U X Orhue, A A Akerobo and C.I Aghimien. Prescribed agric science for senior secondary schools. Revised edition. Idodo Umeh Publishers Ltd. 1999; 14p.

[33] H.McGuinness. Living Soils: Sustainable Alternatives to Chemical Fertilizers, Consumer PolicyInstitute, Consumers Union, 2003 
[34] P.K.Gupta, S. Sahai, N.Singh and CK Dixit. Residue burning in rice wheat cropping system. Causes and the Implications. Curri. Sci.India. 2004; $87 ; 1713-1715$

[35] P. Agamuthu. Challenges and Opportunities in agro- wastes management; An Asian perspective, proceedings of the meeting of first regional 3Rforum in Asian, Tokyo, Japan.2009; 11 - 12November

[36] S.Sahai, C. Sharma, S.K. Singh and P.K Gupta, P.K; An Assessment of Trace gases, Carbon and Nitrogen emissions from field burning of agricultural residues in India. Nutr. Cycl. Agroecosystem.2001;89; $143-157$

[37] S.K.Lohan, H S Jat, A.K Yadav, H.S. Sidhu. Burning issues of paddy residues management in North West States of India. Renew Sustain. Energy Rev 2018; 81; 693 - 706

[38] N.Jain, A. Bhati, and H. Pathak, Crop residual burning in IndiaAresonal air Qual. Research 2014; $14 ; 422-430$.

[39] R.Nagendran, . Agricultural wastes and pollution. Wastes.2016; $341-355$.

[40] F.O. Obi; B.O.Ugwuishiwu, J.N, Nwakaire. Agricultural waste concept, generation, utilization and management. Nijotech. 2016; 35; $957-954$

[41] B. Gadde, S Bonnet, CMenke, C and Garivait, S(2000) Air pollutant emissions from rice straw open field burning in India.Thailand and Phillipines. Environmental pollution; 157; $1554-1558$.

[42] A. Abukari. The Pesticides Law and the Attitudes of PesticidesDealers in the Northern Region of Ghana: Implications for Environmental Security and Human Health. J. Environ. Earth Sci.2015; 5, 106-114.

[43] J.Altman, and A.D.Rovira. Herbicide-pathogen interactions in soil-borne root diseases. Can. J. Plant Pathol. 2017; 11, 166-172.

[44] S.Asfaw, D. Mithofer, and H.Waibel (2009)EU Food Safety Standards, Pesticides Use and Farm-level Productivity: The case of High-value Crops in Kenya. J. Agric. Econ.2016; 60: 645-667.

[45] A.Wumbei, D; Senaeve, M.; Houbraken and P Spanoghe. Pesticides residue analysis in yam from selected markets across Ghana and Belgium: An evaluation of the QUECHERS method. Int. J. Food Contam. 2018; 5, 4.

[46] C A.Bradley, G L Hartman, L M; Wax, W L; Pedersen. Influence of herbicides on Rhizoctonia root and hypocotyl rot of soybean. Crop Prot.2002; 21, 679-687.

[47] W J Ntow, H J Gijzen, P Kelderman and P Drechsel. Farmer perceptions and pesticide use practices in vegetable production in Ghana. Pest Manag. Sci. 2006; 62, 356-365.

[48] E. De Gavelle, B. de Lauzon-Guillain, M A. Charles,C. Chevrier, M.; Hulin, V; Sirot, M; Merlo, and A. Nougadère. Chronic dietary exposure to pesticide residues and associated risk in the French ELFE cohort of pregnant women. Environ. Int.2006; 92-93, 533-542.

[49] L. Kryzanowski, and D C.Penney. Alberta fertilizer guide. Alberta 310-FARM(3276).2004.

[50] S. I. Ume, S.I, E. E. Ebe, C.D. Ochiaka,J S. Ochiaka. Technical Efficiency of Yam Based Intercropping System among Farmers in Abia State, Nigeria (Using Trans - Log Frontier Production Function) International Journal of Research \& Review (www.gkpublication.in); $2017 ; 1(4) ; 14-19$.

[51] K. M. Illyassou, R. Adamou and B. Schiffers. First diet survey in Niger River valley and acute risk assessment for consumers exposed to pesticide residues in vegetables. Tunis. J. Plant Protect.2018; 13, 243-262.

[52] L H.Hileman, Effect of rate of poultry manure application on selected soil chemical properties. Proc. of International Symposium on Livestock Wastes. Am. Soc. of Agric. Engineers. St. Jos. Michigan.2009; pp. 247-248

[53] K.Mahdi Al. (2015)Frequent tillage and its impact on soil quality. Encyclopedia Article ISU Extension andnOutreach Iowa State UniversityState and National Extension Partners, 2015

[54] V E. Enya and J O. Alimba, J.O. Analysis of factors affecting demand from agricultural credit of commercial banks in Nigeria (1986-2005). Journal of Agriculture, forestry and social sciences 2007;5(1): 52-57. 
[55] L SO Liverpool-Tasie, B T Omonona, A, Sanou, and W. Ogunleye. A profitability analysis of fertilizer use for maize production in Nigeria. GISAIA: Policy Paper - 2016; February 2016.

[56] R OIheke Market access, income diversification and welfare status of rural farm households in Abia State. Nigeria. Nigeria Agricultural Journal. 2010; 4(2): 13-18.

[57] CI. Ezeano, S.I, Ume, CC, Okeke, B O, Gbughemobi,;Socio Economic Determinant Factors to Youths Participation in Broilers Production in Imo State of Nigeria.International Journal of Research \& Review (www.gkpublication.in) 2017; 1(4);12 - 19 January

[58] K. Ogungbile and J. Olukosi, J. An overview of the problems of resource poor farmers in Nigeria agriculture. A paper presented on appropriate technology for resource poor farmers. The processing of NFSRN held in Calabar, Cross River State, Nigeria.1999; pp. 14-17.

[59] RPA, Unammah, R.P.A. Agricultural technology generation and transfer strategies for food securities. Proceedings of the $16^{\text {th }}$ Annual zonal Research and Extension, farmers input linkage system (REFILS) Workshop South East/South South zones of Nigeria.2003; $19^{\text {th }}-23$ November.

[60] E C. Okorji. Appropriate technology generation for small scale farmers in Nigeria. Proceeding of the National Farming System Research Network workshop held at Calabar, Cross Rivers State, Nigeria. 2003; 2. 349. 